\title{
STUDIES ON TYPE-SPECIFIC STREPTOCOCCAL ANTIBODIES AS INDICATORS OF PREVIOUS STREPTOCOCCAL INFECTIONS IN RHEUMATIC AND NONRHEUMATIC CHILDREN *
}

Dy MILTON MARKOWITZ with the technical assistance of GOLDIE PELOVITZ

(From the Departments of Pediatrics, Sinai Hospital of Baltimore and the Johns Hopkins School of Medicine, Baltimore, Md.)

(Submitted for publication September 5, 1962; accepted November 24, 1962)

The factors that determine whether a given individual will develop rheumatic fever after a streptococcal pharyngitis have not been clarified. The low incidence of this disease, despite the prevalence of streptococcal respiratory infections, and the high familial incidence suggest a genetic factor. A recent study, however, shows that rheumatic fever does not follow the pattern of a simple recessive gene (1). Rheumatic symptoms develop after mild as well as severe infections due to any one of 50 known types of Group A Streptococci. Attempts to prove that any particular cellular component or enzyme produced by these organisms is the cause of this disease have so far proved negative.

Rheumatic fever is uncommon in children less than five years of age. The mean titers of antistreptococcal antibodies in patients with acute rheumatic fever tend to be higher than in children with uncomplicated streptococcal infections (2). These observations suggested that repeated, closely spaced attacks of streptococcal pharyngitis may be a determining factor (3).

It is usually not possible to obtain a reliable history of remote respiratory infections. Furthermore, even if the illness is recalled, streptococcal pharyngitis usually cannot be differentiated from a sore throat of viral origin. The commonly studied antistreptococcal antibodies, such as antistreptolysin $\mathrm{O}$, are not type-specific and may show a rise in titer after infection with any one of the 50 types of Group A Streptococci. These antibodies usually appear one to two weeks after the infection and in most instances return to normal levels after two to six months.

The only antibody indicative of a type-specific streptococcal infection is the one directed against

* Supported by grant H-5555 from the U. S. Public Health Service. the $\mathrm{M}$ antigen. These type-specific antibodies develop slowly and are usually not detectable until one or two months after an infection (4). In some individuals, in whom the type of the infecting strain was definitely established, homologous typespecific antibodies were demonstrable 32 years after the original infection (5).

TABLE I

General data-clinical and laboratory manifestations of patients with acute rheumatic fever

\begin{tabular}{|c|c|c|c|c|c|c|}
\hline \multirow[b]{2}{*}{ Case } & \multirow[b]{2}{*}{ Age } & \multirow[b]{2}{*}{ Race } & \multicolumn{3}{|c|}{$\begin{array}{l}\text { Rheumatic mani- } \\
\text { festations }\end{array}$} & \multirow{2}{*}{$\begin{array}{c}\text { Laboratory } \\
\text { data- } \\
\text { maximal } \\
\text { ASO } \\
\text { titer* }\end{array}$} \\
\hline & & & $\begin{array}{l}\text { Cardi- } \\
\text { tis }\end{array}$ & $\begin{array}{l}\text { Polyar- } \\
\text { thritis }\end{array}$ & Chorea & \\
\hline \multicolumn{7}{|l|}{ no. } \\
\hline 1 & 11 & $\mathbf{N}$ & & + & & 1,000 \\
\hline 2 & 10 & $\mathbf{N}$ & & + & & 625 \\
\hline 3 & 6 & W & + & + & & 625 \\
\hline 4 & 4 & w & & + & & 333 \\
\hline 5 & 6 & W & + & & & 625 \\
\hline 6 & 6 & w & & + & & 333 \\
\hline 7 & 7 & $\mathrm{~N}$ & + & + & & 1,250 \\
\hline 8 & 13 & W & & + & & 1,000 \\
\hline 9 & 5 & $\mathbf{N}$ & + & + & & 500 \\
\hline 10 & 4 & W & + & + & & 833 \\
\hline 11 & 6 & $\mathbf{N}$ & + & + & & 250 \\
\hline 12 & 8 & $\mathbf{N}$ & & + & & 500 \\
\hline 13 & 11 & W & & + & & 625 \\
\hline 14 & 8 & $\mathbf{N}$ & + & & & 500 \\
\hline 15 & 10 & $\mathrm{~N}$ & & + & & 250 \\
\hline 16 & 7 & $\mathrm{~N}$ & + & + & & 333 \\
\hline 17 & 10 & $\mathbf{N}$ & + & + & & 500 \\
\hline 18 & 7 & W & & + & & 1,000 \\
\hline 19 & 13 & W & + & + & + & 500 \\
\hline 20 & 10 & $\mathbf{N}$ & + & + & & 833 \\
\hline 21 & 4 & $\mathrm{~N}$ & + & + & & 1,250 \\
\hline 22 & 6 & $\mathbf{N}$ & + & + & & 2,500 \\
\hline 23 & 11 & $\mathbf{N}$ & & + & & 500 \\
\hline 24 & 13 & $\mathrm{~N}$ & & + & & 500 \\
\hline 25 & 9 & $\mathbf{N}$ & & + & & 500 \\
\hline 26 & 9 & W & + & & & 1,000 \\
\hline 27 & 12 & W & & + & & 1,000 \\
\hline 28 & 7 & w & + & & & 625 \\
\hline 29 & 13 & w & + & & & 833 \\
\hline 30 & 11 & $\mathbf{N}$ & + & & & 625 \\
\hline 31 & 11 & $\mathrm{~N}$ & + & & & 500 \\
\hline 32 & 11 & W & + & & & 500 \\
\hline
\end{tabular}

* Antistreptolysin titer (ASO) expressed in Todd units. A titer of $250 \mathrm{U}$ is at the upper limit of normal for this age group in the community
under study. 
TABLE II

Example of a biologic assay for the selection of a streptococcal strain suitable for the bactericidal test for type-specific antibody*

\begin{tabular}{|c|c|c|c|c|c|}
\hline \multirow[b]{2}{*}{ Strain } & \multirow{2}{*}{$\begin{array}{l}\text { Test conditions: } \\
0.1 \text { ml culture dilution } \\
0.3 \text { ml heparinized normal } \\
\text { human blood }\end{array}$} & \multicolumn{4}{|c|}{ No. of colonies from culture dilution: } \\
\hline & & $10^{-5}$ & $1: 4$ & $1: 16$ & $1: 64$ \\
\hline $\begin{array}{c}\text { Type } 3 \\
\text { (Hirsch strain) }\end{array}$ & $\begin{array}{l}\text { No. Streptococci at } \\
\text { onset of test }\end{array}$ & 169 & 47 & 9 & 5 \\
\hline & $\begin{array}{l}\text { No. Streptococci at } \\
\text { end of test } \\
\text { 1) Rotated tubes } \\
\text { 2) Stationary tubes }\end{array}$ & $\begin{array}{c}2,000 \dagger \\
\mathrm{Cf}\end{array}$ & $\begin{array}{l}557 \\
4,000 \dagger\end{array}$ & $\begin{array}{c}339 \\
500-2,000 \ddagger\end{array}$ & $\begin{array}{r}50 \\
288\end{array}$ \\
\hline
\end{tabular}

* Method of Lancefield, reference 5.

$\dagger$ Estimated count.

$\ddagger$ Confluent.

Since a second infection due to the same type of Streptococcus rarely occurs, the presence of antibodies against $M$ antigen can be taken as evidence of a single previous infection with a homologous type. A study of type-specific streptococcal antibodies was undertaken in an effort to determine whether patients with an initial attack of rheumatic fever have had a greater number of previous episodes of streptococcal infections than nonrheumatic children of a similar age.

\section{METHODS}

Clinical material. Two groups of children were studied, 32 patients with acute rheumatic fever and 35 nonrheumatic individuals who served as controls. The patients with acute rheumatic fever were selected from the pediatrics wards of the Johns Hopkins and Sinai Hos- pitals over a two-year period (1960-1961). Patients were accepted in the study if they fulfilled the Jones criteria for the diagnosis of rheumatic fever and if they were experiencing their first episode of this disease. The manifestations exhibited by these patients are shown in Table I. Nineteen of the 32 patients had carditis. All but two of the children had an antistreptolysin $\mathrm{O}$ titer above $250 \mathrm{U}$. Antibodies to other streptococcal enzymes were not included, and may have been elevated in these individuals.

The control group consisted of 35 children selected during the same two-year period from the patients admitted for elective surgery or from the general outpatient departments of the hospitals above. The children in the control group had a negative history for rheumatic fever, had no evidence of heart disease, and were not receiving antibiotics at the time the blood sample was obtained. Five children in the control group had a family history of rheumatic fever. The children in both groups came from the same socio-economic environment, and

TABLE III

Example of a test series for antitype 12 antibodies by the indirect bactericidal test

\begin{tabular}{|c|c|c|c|c|c|c|}
\hline \multirow[b]{3}{*}{ Source of serum } & \multirow[b]{3}{*}{ Strain tested } & \multicolumn{4}{|c|}{ No. of colonies from culture dilutions } & \multirow{3}{*}{$\begin{array}{l}\text { Homologous } \\
\text { type-specific } \\
\text { antibody }\end{array}$} \\
\hline & & $10^{-5}$ & $\begin{array}{c}1: 4 \\
\text { Inoculum }\end{array}$ & $1: 16$ & $1: 64$ & \\
\hline & & \multicolumn{4}{|c|}{102 After 3 hours growth } & \\
\hline $\begin{array}{l}\text { Normal adult* } \\
\text { Rheumatic group }\end{array}$ & & $500-2,000 \dagger$ & 300 & 171 & 26 & \\
\hline $\begin{array}{l}\text { Case } 11 \\
\text { Case } 17 \\
\text { Case } 18\end{array}$ & $\begin{array}{c}\text { Type 12 } \\
\text { (Strain E, 14/104/9) } \ddagger\end{array}$ & $\begin{array}{l}210 \\
542 \\
100\end{array}$ & $\begin{array}{r}88 \\
238 \\
64\end{array}$ & $\begin{array}{l}21 \\
69 \\
11\end{array}$ & $\begin{array}{r}0 \\
30 \\
0\end{array}$ & $\begin{array}{l}+ \\
+\end{array}$ \\
\hline \multicolumn{7}{|l|}{ Control group } \\
\hline $\begin{array}{l}\text { Case } 9 \\
\text { Case } 15 \\
\text { Case } 21\end{array}$ & & $\begin{array}{r}541 \\
51 \\
444\end{array}$ & $\begin{array}{r}162 \\
21 \\
177\end{array}$ & $\begin{array}{r}77 \\
5 \\
89\end{array}$ & $\begin{array}{r}15 \\
0 \\
20\end{array}$ & + \\
\hline
\end{tabular}

* Serum from donor known not to contain antibodies against Type 12.

† Estimated count.

$\ddagger$ This strain was kindly supplied by Dr. Rebecca C. Lancefield. 
TABLE IV

Example of a test series for antitype 6 antibodies by the indirect bactericidal test

\begin{tabular}{|c|c|c|c|c|c|c|}
\hline \multirow[b]{3}{*}{ Source of serum } & \multirow[b]{3}{*}{ Strain tested } & \multicolumn{4}{|c|}{ No. of colonies from culture dilutions } & \multirow{3}{*}{$\begin{array}{l}\text { Homologous } \\
\text { type-specific } \\
\text { antibody }\end{array}$} \\
\hline & & $1: 4$ & $\begin{array}{c}1: 16 \\
\text { Inoculum }\end{array}$ & $1: 64$ & $1: 128$ & \\
\hline & & \multicolumn{4}{|c|}{ After 3 hours growth } & \\
\hline $\begin{array}{l}\text { Normal adult* } \\
\text { Rheumatic group }\end{array}$ & & $2,000-4,000 \dagger$ & 392 & 111 & 89 & \\
\hline $\begin{array}{l}\text { Case } 29 \\
\text { Case } 25 \\
\text { Case } 28\end{array}$ & $\begin{array}{c}\text { Type } 6 \\
\text { (Alice strain) }\end{array}$ & $\begin{array}{c}85 \\
500-2,000 \dagger \\
500-2,000 \dagger\end{array}$ & $\begin{array}{r}29 \\
331 \\
350\end{array}$ & $\begin{array}{r}6 \\
195 \\
108\end{array}$ & $\begin{array}{r}0 \\
43 \\
31\end{array}$ & + \\
\hline \multicolumn{7}{|l|}{ Control group } \\
\hline $\begin{array}{l}\text { Case } 22 \\
\text { Case } 34 \\
\text { Case } 30\end{array}$ & & $\frac{82}{2,000-4,000 \dagger}$ & $\begin{array}{r}0 \\
279 \\
13\end{array}$ & $\begin{array}{r}0 \\
152 \\
0\end{array}$ & $\begin{array}{r}0 \\
38 \\
0\end{array}$ & $\begin{array}{l}+ \\
+\end{array}$ \\
\hline
\end{tabular}

* Serum from donor known not to contain antibodies against Type 6.

$\dagger$ Estimated count.

were matched as closely as possible for race and age. Seventeen of the rheumatic group and 15 of the control group were Negroes. They ranged in age from 4 to 13 years, with a mean of 8.4 years for the rheumatic group and 8.5 years for the control group.

Because of the known suppressive effect of antibiotics on the formation of type-specific antibodies (6), an attempt was made to evaluate each child's past history of exposure to antibiotics. Although it was not possible to obtain a completely accurate assessment, the children in both groups did not differ significantly in this respect. All of the children came from a clinic population. None were under continuous or close medical supervision, and none had received frequent or prolonged courses of antibiotics.

Laboratory methods. Blood was drawn aseptically from each child. The serum was separated and stored in the frozen state without preservatives. With the exception of a few patients in the rheumatic fever group, enough serum was obtained to do all of the bactericidal tests on the initial sample. Specimens were obtained from patients with acute rheumatic fever within three weeks from onset of symptoms.

The serum of each patient was tested for antibodies against the following types of Group A Streptococci: $1,2,3,4,5,6,12,13,18,23,25,28$, and 30 . The types were selected because of their known incidence in the community under study; $95 \%$ of the typeable strains obtained from random throat cultures in the Baltimore area over the past three years were among the 13 types listed above (see Table IX).

Care was taken to select strains suitable for the bactericidal test. It has been shown that strains with an intermediate amount of $\mathrm{M}$ antigen are best for the detection of antibody in low concentration (5). Dr. Rebecca C. Lancefield kindly furnished satisfactory strains for Types $2,4,12,18,23$, and 30 . Strains for Types $1,3,5$, $6,13,25$, and 28 were selected from lyophilized stock cultures and were tested for their $M$ producing properties by a method described by Lancefield (5). This is a

TABLE V

Type-specific antibodies in sera of children with acute rheumatic fever

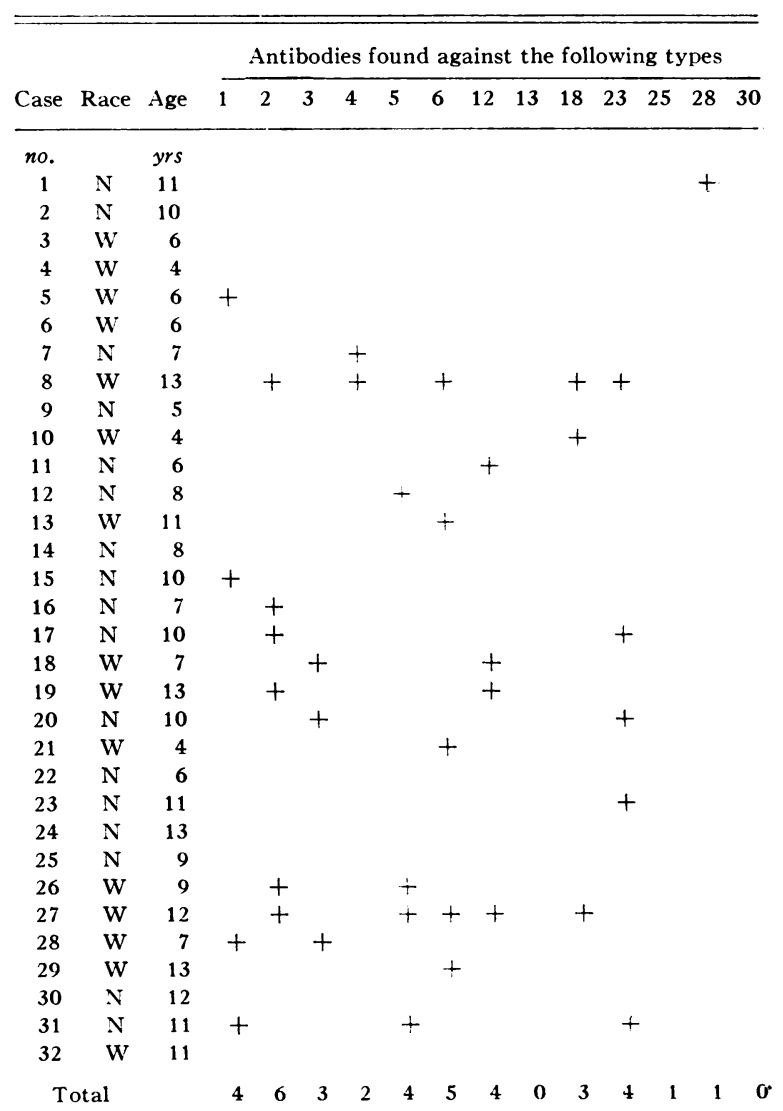


biologic assay which tests the ability of a strain to resist phagocytosis in normal human blood in rotated as compared to stationary tubes. A strain was considered suitable for the bactericidal test if it grew well in normal blood but there was less growth in the rotated tubes than in the stationary set. An example of a biologic assay carried out for a Type 3 strain which proved to be satisfactory is shown in Table II.

The indirect bactericidal test was used to detect typespecific antibodies (7). Suitable strains of a known streptococcal type were grown overnight in rabbit blood broth, after which a heavily seeded two-hour subculture in Todd-Hewitt broth was prepared. A $10^{-5}$ dilution of the culture was made and this was further diluted serially to $1: 4,1: 16,1: 64$, and $1: 128$. Tubes containing $0.1 \mathrm{ml}$ of each dilution were prepared, and to each were added $0.05 \mathrm{ml}$ of test serum and $0.3 \mathrm{ml}$ of freshly drawn heparinized human blood as a source of phagocytes $(0.1$ $\mathrm{ml}$ of heparin containing $1,000 \mathrm{U}$ of heparin for $20 \mathrm{ml}$ of blood). A control serum obtained from adult donors who were known not to harbor antibodies for the strep-

TABLE VI

Type-specific antibodies in sera of nonrheumatic children (control group)

\begin{tabular}{|c|c|c|c|c|c|c|c|c|c|c|c|c|c|c|c|}
\hline \multirow[b]{2}{*}{ Case } & \multirow[b]{2}{*}{ Race } & \multirow[b]{2}{*}{ Age } & \multicolumn{13}{|c|}{ Antibodies found against the following types } \\
\hline & & & 1 & 2 & 3 & 4 & 5 & 6 & 12 & 13 & 18 & 23 & 25 & 28 & 30 \\
\hline no. & & $y r s$ & & & & & & & & & & & & & \\
\hline 1 & w & 5 & & & + & & & & + & & & & & & \\
\hline 2 & $\mathbf{N}$ & 4 & + & + & & & & & + & & & & & & \\
\hline 3 & W & 5 & & & & & & & & & & & & & \\
\hline 4 & W & 9 & & & & & & & & & & & & & \\
\hline 5 & W & 10 & & & & & & + & + & & & & & & \\
\hline 6 & W & 10 & & & & & + & + & & & & & & & \\
\hline 7 & $\mathbf{N}$ & 7 & & & & & & & & & & & & & \\
\hline 8 & $\mathbf{N}$ & 13 & & & & & & & & & + & & & & \\
\hline 9 & $\mathbf{N}$ & 9 & & & & & & + & & & & & & & \\
\hline 10 & $\mathbf{N}$ & 11 & & & & & & & & & & & & & \\
\hline 11 & W & 8 & & & & + & & & & & & & & & \\
\hline 12 & W & 6 & & & & & & & & & & & & & \\
\hline 13 & $\mathbf{w}$ & 8 & & & & & & & & & & & & & \\
\hline 14 & W & 10 & & & & & & & & & & & & & \\
\hline 15 & $\mathbf{N}$ & 9 & & + & & & & & + & & & & & & \\
\hline 16 & W & 14 & & & + & & & + & & & & & & & \\
\hline 17 & W & 6 & & & & & & & & & & & & & \\
\hline 18 & W & 6 & & & & & & & & & & & & & \\
\hline 19 & W & 13 & & & & & + & & & & & & & & \\
\hline 20 & $\mathbf{N}$ & 8 & & & & & & & & & & & & & \\
\hline 21 & $\mathrm{~N}$ & 7 & & & & & & & & & & & & & \\
\hline 22 & W & 12 & & & & & + & + & + & & & & & & \\
\hline 23 & $\mathbf{N}$ & 12 & & & & + & & & & & & & & & \\
\hline 24 & $\mathbf{N}$ & 10 & & & & & & & & & & & & & \\
\hline 25 & W & 7 & & & & & & & & & & & & & \\
\hline 26 & W & 8 & & & & & & + & & & & & & & \\
\hline 27 & W & 10 & & & + & & & & & & & & & & \\
\hline 28 & $\mathbf{N}$ & 7 & & & & & & + & + & & & & & & \\
\hline 29 & W & 11 & & & & & & & & & & & & & \\
\hline .30 & W & 11 & & & & + & & + & & & & & & & \\
\hline .31 & $\mathrm{~N}$ & 7 & & & & & & & & & & & & & \\
\hline .32 & $\mathbf{N}$ & 9 & & + & & & & & + & & & & & & \\
\hline .33 & W & 5 & & & & & & & & & & & & & \\
\hline 34 & $\mathbf{N}$ & 9 & & & & & & & & & & & & & \\
\hline .35 & $\mathrm{~N}$ & 12 & & & & & & & & & & & & & \\
\hline \multicolumn{2}{|c|}{ Total } & & 1 & 3 & 3 & 3 & 3 & 8 & 7 & 0 & 1 & 0 & 0 & 0 & 0 \\
\hline
\end{tabular}

TABLE VII

Comparison of number of patients with single and multiple antibodies in rheumatic and control groups

\begin{tabular}{lll}
\hline \hline & $\begin{array}{c}\text { Rheumatic } \\
\text { group }\end{array}$ & $\begin{array}{c}\text { Control } \\
\text { group }\end{array}$ \\
\hline Patients studied & 32 & 35 \\
$\begin{array}{l}\text { Patients with type- } \\
\text { specific antibodies }\end{array}$ & $21(65 \%)$ & $18(52 \%)$ \\
Against single type & 12 & 9 \\
Against multiple types & 9 & 9 \\
\hline
\end{tabular}

tococcal types under study was included in each series of tests. Since many of the patients with acute rheumatic fever were receiving penicillin therapy, $0.05 \mathrm{ml}$ of penicillinase $(100 \mathrm{U}$ per $10 \mathrm{ml})$ was added to each tube.

The prepared tubes were placed in a rotating machine driven at 6 to $8 \mathrm{rpm}$ and incubated at $37^{\circ} \mathrm{C}$. After 3 hours of rotation, pour plates were made with $0.1 \mathrm{ml}$ from each tube and agar containing 5\% sheep blood. To determine the size of the inoculum at the start of the test, additional pour plates were made with $0.1 \mathrm{ml}$ of each of the original serial culture dilutions mixed with sheep blood agar. The plates were incubated overnight, and the number of colonies which grew out from the inoculum was compared with colony count or estimate 1 from the control and test mixtures. The method was considered satisfactory if 1 ) the inoculum was small (from 100 to 250 colonies in the $10^{-5}$ dilution and from 1 to 15 colonies in the $1: 128$ dilution) and 2) a vigorous growth occurred in the normal control serum. The unknown serum was considered positive for antibody against the homologous type if there was a significant suppression of growth in each culture dilution mixed with test serum as compared to the control serum and the result could be reproduced. The protocols of two representative test series are shown in Tables III and IV.

\section{RESULTS}

Type-specific antibodies: rheumatic fever groups. The results obtained in children with acute rheumatic fever are presented in Table $\mathrm{V}$. Type-specific antibodies in various combinations were demonstrated in 21 of 32 patients. Antibodies against more than one type were found in nine patients, and in two children (Cases 8 and 27), antibodies against five types were noted. The latter children were 13 and 12 years of age, well above the mean age for the group ( 8.4 years).

1 Plates with 500 colonies or less were counted. Four thousand colonies indicate a plate with innumerable colonies with areas of unhemolyzed blood. Five hundred to 2,000 colonies and 2,000 to 4,000 colonies were estimated by comparison. 
Antibodies were found most commonly against Types $2,6,12,1,5$, and 23 , but no single type predominated. No homologous antibodies were demonstrated against Types 13 and 30 .

Type-specific antibodies: control group. In Table VI, the record of the antibodies found in nonrheumatic children is presented. Antibodies were demonstrated in 18 of 35 children. Nine children had antibodies against more than one type. Antibodies for Types 6 and 12 were the most common, and the remainder were distributed among six other types. No antibodies were found against 13, 23, 25, 28, and 30 .

Comparison of type-specific antibodies in rheumatic and control groups. A comparison of the type-specific antibodies found in both groups is presented in Table VII. Antibodies were demonstrated in 21 of $32(65 \%)$ rheumatic subjects as compared with 18 of $35(52 \%)$ control children. The difference is not statistically significant ( $p$ value $=>0.05)$. When patients with antibodies against more than one type are considered separately, the groups resemble each other even more closely: 9 of 32 rheumatic patients and 9 of 35 control children had multiple antibodies.

Relationship of age to the frequency of typespecific antibodies. An analysis of the data with respect to age was made by dividing the entire group of 67 children into two age periods: preschool age of 4 to 6 years (16 patients) and school age of 7 to 13 years (51 patients). Antibodies were found in 6 of the $16(37 \%)$ preschool subjects and in 33 of $51(64 \%)$ of school children (Table VIII). Antibodies against more than one type were present in two of the preschool group $(12 \%)$ and in 16 of the school group (28\%).

When each age period is analyzed separately for the rheumatic and control groups, the number of children with single and multiple antibodies is essentially the same in both groups. Thus the older children were more likely to have antibodies against more than one type, but regardless of age, multiple type-specific antibodies were not found more commonly in the rheumatic individual than in the nonrheumatic subject.

Distribution of antibodies for each homologous type and the frequency of strains obtained from random throat cultures. In Table IX (left column) there is recorded the incidence of the typeable streptococcal strains encountered among approximately 500 throat cultures obtained at random in the community over the past three years. Type 12 was found in $22 \%$. Types 1,2 , and 4 were next most common, in the order listed. Altogether these four types made up $60 \%$ of the typeable strains. The remainder were distributed among the other nine types.

In the left column of Table IX there is listed the percentage of patients with homologous antibodies for each of the 13 types listed. Antibodies were most common against Type 6,12 , and 2 and were somewhat less frequent against Types 5, 3, 1, and 4. There were few or no patients with homologous antibodies against Types $25,28,13$, and 30.

Relationship of the type-specific antibody pattern and the antistreptolysin $O$ titer in the rheumatic patients. The type-specific antibody pattern and the corresponding maximal antistreptolysin $\mathrm{O}$ titer for each patient with acute rheumatic fever is shown in the form of a scattergram (Table $\mathrm{X}$ ). It will be noted that the magnitude of the antistreptolysin $\mathrm{O}$ titer bore little or no relationship to the type-specific antibody pattern. Patients with no demonstrable type-specific antibodies against the 13 types tested were as likely to have high antistreptolysin $\mathrm{O}$ titers as the patients with antibodies against two or more types.

TABLE VIII

Relationship of age to frequency of type-specific antibodies

\begin{tabular}{|c|c|c|c|c|c|c|c|c|c|}
\hline \multirow[b]{3}{*}{ Age group } & \multicolumn{9}{|c|}{ Patients with homologous type-specific antibodies } \\
\hline & \multicolumn{3}{|c|}{ Total group } & \multicolumn{3}{|c|}{ Rheumatic group } & \multicolumn{3}{|c|}{ Control group } \\
\hline & No. & $\begin{array}{l}\text { Single } \\
\text { type }\end{array}$ & $\begin{array}{c}\text { Multiple } \\
\text { types }\end{array}$ & No. & $\begin{array}{l}\text { Single } \\
\text { type }\end{array}$ & $\underset{\text { types }}{\text { Multiple }}$ & No. & $\begin{array}{l}\text { Single } \\
\text { type }\end{array}$ & $\underset{\text { types }}{\text { Multiple }}$ \\
\hline $\begin{array}{l}4-6 \text { yrs } \\
7-13 \text { yrs }\end{array}$ & $\begin{array}{l}16 \\
51\end{array}$ & $\begin{array}{r}4 \\
17\end{array}$ & $\begin{array}{r}2 \\
16\end{array}$ & $\begin{array}{r}9 \\
23\end{array}$ & $\begin{array}{l}4 \\
8\end{array}$ & $\begin{array}{l}0 \\
9\end{array}$ & $\begin{array}{r}7 \\
28\end{array}$ & $\begin{array}{l}0 \\
9\end{array}$ & $\begin{array}{l}2 \\
7\end{array}$ \\
\hline
\end{tabular}


TABLE IX

A comparison of the distribution of antibodies among 13 types tested and the frequency of strains encountered in the community

\begin{tabular}{ccc}
\hline \hline & $\begin{array}{c}\text { \% Types found } \\
\text { in random } \\
\text { throat cultures } \\
\text { from patients } \\
\text { with typeable } \\
\text { strains* }\end{array}$ & $\begin{array}{c}\% \text { Patients with } \\
\text { homologous } \\
\text { antibodies } \\
\text { for each } \\
\text { typet }\end{array}$ \\
\hline 1 & 20 & 7 \\
2 & 14 & 13 \\
3 & 4 & 9 \\
4 & 14 & 7 \\
5 & 1 & 10 \\
6 & 4 & 19 \\
12 & 22 & 16 \\
13 & 3 & 0 \\
18 & 4 & 6 \\
23 & 2 & 6 \\
25 & 0.5 & 2 \\
28 & 6 & 2 \\
30 & 0.5 & 0 \\
Other & 5.0 &
\end{tabular}

* Results of approximately 500 throat cultures obtained between 1959-1961. Forty \% of the strains were typeable.

$\dagger$ Entire group of 67 patients.

\section{DISCUSSION}

The results of this study suggest that the incidence of past streptococcal disease, exclusive of the infection which triggered the acute attack, is probably no greater in the rheumatic subject that in the nonrheumatic individual. By utilizing the bactericidal test, type-specific antibodies were detected against one or more of 13 prevalent types of Group A Streptococci in $65 \%$ of patients with acute rheumatic fever and in $52 \%$ of control children. The difference is not statistically significant. The similarity between the groups is more striking when children with antibodies against more than one type are considered separately: $28 \%$ of the rheumatic group and $25 \%$ of the control series had multiple type-specific antibodies.

The findings obtained in this study provide no evidence to support the concept that susceptibility to rheumatic fever is related to an inordinately high incidence of prior streptococcal infections. There are no data available on the incidence of clinically observed streptococcal infection in patients who subsequently develop their initial attack of rheumatic fever. Taranta (8) documented streptococcal illness in a group of individuals with a known past history of rheumatic fever, and in this highly susceptible group, it is significant that no correlation was found between the recur- rence rate and the number of streptococcal infections prior to the one which initiated the recurrent attack. It should be pointed out, however, that although the type-specific antibody pattern reflects the incidence of past streptococcal disease, it is not possible to know when and in what sequence the remote infections occurred. Therefore, the data do not exclude the possibility that the past infections may have been more closely spaced in the rheumatic individuals. Studies by Winblad, Malmros, and Wilander (9) suggest that rheumatic fever is more likely to occur following cross-infection with a second type of Streptococcus. On the other hand, Stetson (10) found no relationship between closely spaced infections and the attack rate of rheumatic fever.

Rantz, Maroney, and Di Capro (11) have shown that the magnitude of the antistreptolysin $\mathrm{O}$ response to streptococcal infections increases from infancy through childhood and this change is probably a function of repeated infections with these organisms. It has been inferred from these studies that rheumatic fever is infrequent in preschool children because the response to antigenic stimuli is less marked in young than in older individuals. If this theory is correct, then it would seem reasonable to expect that when a young child develops rheumatic fever he probably has had greater exposure to streptococcal disease than other children in a similar age group. The data obtained in this study do not support this hypothesis. Although there were only nine patients with acute rheumatic fever in this study who were four to six years of

TABLE $\mathrm{X}$

Relationship of type-specific antibody pattern to antistreptolysin $O$ titer in 32 patients with acute rheumatic fever

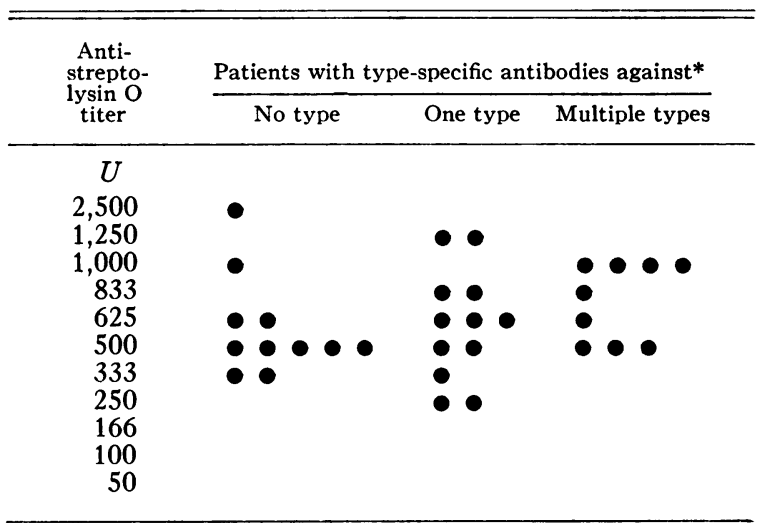

* Sera of each patient tested against 13 types. 
age, more than half had no type-specific antibodies at all, and none had antibodies against more than one type.

The streptococcal antibody response to extracellular antigens is generally higher in the rheumatic group than in patients with uncomplicated streptococcal infections (2). The significance of this finding is not known. Rheumatic and nonrheumatic subjects do not show any difference in their ability to form antibody to nonstreptococcal antigens (12). If the immunologic hyperreactivity of the rheumatic individual for streptococcal antigens were related to the frequency of previous streptococcal infections, then a correlation might be anticipated between the magnitude of the antistreptolysin $\mathrm{O}$ titer and the number of type-specific antibodies in a given individual. No such relationship was found. Patients with acute rheumatic fever who had the highest antistreptolysin $O$ titers did not have a greater number of typespecific antibodies than patients with lower titers.

Epidemiologic data indicate that a relatively small number of streptococcal types tend to persist in a given population for several years, waxing and waning at different times (13). It was therefore of interest to compare the prevalence of strains isolated from throat cultures obtained at random in the community and the incidence of homologous antibodies. Types $12,1,2$, and 4 were isolated most commonly and accounted for $60 \%$ of the typeable strains. Homologous antibodies against at least one of these types were found in $43 \%$ of the patients studied. The frequency of Type 12 isolations (22\%) as well as the prevalence of antibodies against this strain $(16 \%)$ compare closely with the findings of Siegel, Johnson, and Stollerman (14). Antibodies against Types 5 and 6 were found in a relatively high percentage of patients $(10 \%$ and $19 \%$, respectively), and yet the incidence of isolations of these strains from throat cultures were low (1\% and $4 \%$, respectively). It is possible that antibodies against these two types reflect a prior prevalence of types which have become less common in the more recent years of the culture survey.

It is very unlikely that an individual's complete past streptococcal history was revealed by the type-specific antibody patterns obtained in this study. Additional antibodies might have been demonstrated if more than 13 types had been included. Furthermore, the bactericidal test may not be sufficiently sensitive to detect low levels of antibody. Recent studies by Potter, Stollerman, and Siegel (15) have shown that type-specific antibodies may disappear from the blood within two to three years in $50 \%$ of the patients and that the titer can be recalled by small doses of cell wall vaccines of homologous types. Also, penicillin therapy for past infections may have suppressed anti-M antibody in some children included in the study. It is not possible to assess the extent that the above factors may have modified the antibody patterns observed, but there is no reason to suspect that these factors did not apply equally to both groups of children.

The purpose of this investigation was to determine the remote streptococcal history of patients and to exclude insofar as possible the effect of recent infections on the type-specific antibody pattern. Since anti-M antibodies form slowly and since serum specimens were obtained early in the attack of rheumatic fever in all but a few patients, it is likely that the type-specific antibody patterns observed did not reflect the recent streptococcal illness. It is possible, however, that among the small number of rheumatic subjects in whom specimens were obtained three weeks after the onset of the attack, measurable type-specific antibody from a recent infection may have occurred. This might account for the slightly higher incidence of typespecific antibodies observed in the rheumatic group.

The two groups of children varied markedly in respect to evidence of recent streptococcal infection. Thirty of 32 patients in the rheumatic group had an antistreptolysin $\mathrm{O}$ titer above $250 \mathrm{U}$, while five children in the control group had titers above this level. These findings are in keeping with the established fact that a preceding streptococcal infection can be demonstrated in almost every case of rheumatic fever, and it should not be inferred from the data obtained on type-specific antibodies that any doubt is cast on this wellknown relationship.

SUMMARY AND CONCLUSIONS

1. Type-specific antibodies against 13 prevalent types of Group A Streptococci were determined 
by bactericidal tests on the sera of a group of patients with acute rheumatic fever and of a group of suitable control children.

2. Type-specific antibodies against one or more types were demonstrated in $65 \%$ of patients with acute rheumatic fever and in $52 \%$ of control children. The rheumatic patients did not have antibodies against a greater number of types than the control children.

3. Antibodies against more than one type occurred more commonly among the older children of both groups.

4. No correlation could be demonstrated between the magnitude of the antistreptolysin $\mathrm{O}$ titer and the type-specific antibody pattern in patients with acute rheumatic fever.

5. Since the presence of type-specific antibody is evidence of a past infection with an homologous type, the data obtained suggest that the rheumatic host has not had more frequent streptococcal infections prior to the first attack than the nonrheumatic individual.

\section{REFERENCES}

1. Taranta, A., S. Torosoag, J. Metrakos, and W. Jegier. Rheumatic fever in monozygotic and dizygotic twins. Circulation 1959, 20, 778.

2. McCarty, M. The antibody response to streptococcal infection in Streptococcal Infections, M. McCarty, Ed. New York, Columbia University Press, 1954.

3. Rantz, L. A., P. J. Boisvert, and W. W. Spink. Etiology and pathogenesis of rheumatic fever. Arch. intern. Med. 1945, 76, 131.

4. Kuttner, A. G., and T. F. Lenert. The occurrence of bacteriostatic properties in the blood of patients after recovery from streptococcal pharyngitis. J. clin. Invest. 1944, 23, 151.
5. Lancefield, R. C. Persistence of type-specific antibodies in man following infection with Group $A$ streptococci. J. exp. Med. 1959, 110, 271.

6. Daikos, G., and L. Weinstein. Streptococcal bacteriostatic antibody in patients treated with penicillin. Proc. Soc. exp. Biol. (N. Y.) 1951, 78, 160.

7. Lancefield, R. C. Occurrence of $R$ antigen specific for Group A type 3 streptococci. J. exp. Med. 1958, 108, 329.

8. Taranta, A. Factors associated with the rheumatic fever attack rate following streptococcal infection. Arthr. and Rheum. 1961, 4, 303.

9. Winblad, S., H. Malmros, and O. Wilander. Studies in the pathogenesis of rheumatic fever. The antistreptolysin titre in acute tonsillitis and rheumatic fever. Acta med. scand. 1947, 196, 533.

10. Stetson, C. A. The relation of antibody response to rheumatic fever in Streptococcal Infections, $M$. McCarty, Ed. New York, Columbia University Press, 1954.

11. Rantz, L. A., M. Maroney, and J. M. Di Caprio. Antistreptolysin $\mathrm{O}$ response following hemolytic streptococcus infection in early childhood. Arch. intern. Med. 1951, 87, 360.

12. Kuhns, W. J., and M. McCarty. Studies of diphtheria antitoxin in rheumatic fever subjects : analysis of reactions to the Shick test and of antitoxin responses following hyperimmunization with diphtheria toxoid. J. clin. Invest. 1954, 33, 759.

13. Wannamaker, L. W. The epidemiology of streptococcal infections in Streptococcal Infections, $M$. McCarty, Ed. New York, Columbia University Press, 1954.

14. Siegel, A. C., E. E. Johnson, and G. H. Stollerman. Controlled studies of streptococcal pharyngitis in a pediatric population: behavior of type-specific immune response. New Engl. J. Med. 1961, 265, 566.

15. Potter, E. V., G. H. Stollerman, and A. C. Siegel. Recall of type specific immunity by vaccination of human beings with Group A streptococcal cell wall vaccines (abstract). J. clin. Invest. 1960, 39, 1018. 